\title{
Pregnant women need vitamin D for neonatal health
}

\author{
Mitch Blair professor of paediatrics and child public health \\ Department of Paediatrics and Child Health, Northwick Park Hospital, Harrow HA1 3UJ, UK
}

Spector and Levy did not discuss the needs of pregnant women and neonates for vitamin D in winter months. ${ }^{1}$ Vitamin D deficiency in pregnancy is common, particularly among women with dark skin. ${ }^{2}$ A recent Cochrane review found that suboptimal levels were associated with lower birth weight, head circumference, and length. ${ }^{3}$ Deficient levels in infants and toddlers are associated with neonatal hypocalcemic seizures, rickets, and cardiomyopathy. The Royal College of Paediatrics and Child Health and the British Paediatric Surveillance Unit are currently establishing the incidence of nutritional rickets in a UK-wide survey, which should clarify the true burden when it reports in $2017 .{ }^{4}$

Supplementation in pregnancy is an imprecise public health measure; we don't know exactly who should take vitamin D or how much is required to optimise neonatal metabolism and bone health. ${ }^{56}$ We should be moving towards a more personalised era of nutritional health based on genotype and microbiomic analysis, as the technology allows. Until we have that degree of precision, and while we wait for the definitive results of antenatal supplementation trials, all pregnant women at risk should take a daily equivalent dose of 400-600 IU of vitamin
D with the specific aim of reducing the known adverse neonatal health consequences associated with deficiency.

Competing interests: None declared.

1 Spector TD, Levy L. Should healthy people take a vitamin D supplement in winter months? BMJ 2016;355:i6183. doi:10.1136/bmj.i6183 pmid:27881362

2 McAree T, Jacobs B, Manickavasagar T, et al. High levels of vitamin D deficiency in pregnancy-a failure of public health policy?Arch Dis Child 2011;96(Suppl 1):A1. doi:10. 1136/adc.2011.212563.2 pmid:21495277.

3 De-Regil LM, Palacios C, Lombardo LK, Peña-Rosas JP. Vitamin D supplementation for women during pregnancy. Cochrane Database Syst Rev 2016;1:CD008873.pmid: 26765344.

4 Royal College of Paediatrics and Child Health. BPSU surveillance of nutritional rickets. http://www.rcpch.ac.uk/bpsu-nutritional-rickets-presenting-secondary-care-children-andyoung-people-under-age-sixteen-uk-an

5 Aghajafari F, Field CJ, Kaplan BJ, et al. APrON Study Team. The current recommended vitamin $\mathrm{D}$ intake guideline for diet and supplements during pregnancy is not adequate to achieve vitamin D sufficiency for most pregnant women. PLoS One 2016;11:e0157262. doi:10.1371/journal.pone.0157262 pmid:27367800

6 Eggemoen ÅR, Falk RS, Knutsen KV, et al. Vitamin D deficiency and supplementation in pregnancy in a multiethnic population-based cohort. BMC Pregnancy Childbirth 2016;16:7. doi:10.1186/s12884-016-0796-0 pmid:26785795.

Published by the BMJ Publishing Group Limited. For permission to use (where not already granted under a licence) please go to http://group.bmj.com/group/rights-licensing/ permissions 